\title{
Mountain Gloom and Mountain Glory: The Genealogy of an Idea
}

Dawn L. Hollis, University of St Andrews

\section{Acknowledgements:}

This article is partially the result of my PhD research (Rethinking Mountains: Ascents, Aesthetics, and Environment in Early Modern Europe. University of St Andrews, 2016) which was funded by the AHRC. Further development of the piece has taken place under a Leverhulme Trust Project Grant. Warm thanks are due to Bernhard Struck, Sarah Easterby-Smith, Peter H. Hansen, Jason König, Kelsey Jackson Williams, and to the ISLE reviewers for their advice and commentary on various iterations of this article. 


\section{Mountain Gloom and Mountain Glory: The Genealogy of an Idea}

In 1959, the literary scholar Marjorie Hope Nicolson set out to solve "a basic problem in the history of taste". This problem was one of why, and how, attitudes towards mountains had changed "so spectacularly" in English literature and culture between the seventeenth and eighteenth centuries (vii). The monograph in which Nicolson sought to solve this problem drawing together poetry, theology, and natural philosophy - has gone on to attain the rare status of a sixty-year-old academic text which is still regularly cited to this day. Its sur-title, as much as anything else - Mountain Gloom and Mountain Glory - is now emblematic of a widely-accepted concept within the history of landscape: that of a European-wide shift from premodern distaste and fear towards mountains, to the modern context of climbing, enthusiasm, and awe.

Nicolson's monograph is cited across academic fields: in the history of landscape and environment, in the philosophical study of aesthetics, in literary studies and accounts of mountaineering. ${ }^{1}$ Only relatively recently have scholars sought to modify or challenge the thesis of "mountain gloom" (Koelb). ${ }^{2}$ Several studies which have engaged closely with Nicolson's work have sought merely to "push back" the date of the shift from gloom to glory -

\footnotetext{
1 E.g. Walsham 381-391, Thomas 258-260 and 290; Smout 10-18, Schama 45, Heringham 83-85, Rueger 313, Parsons 22, Shapsay 184, Bourassa 12, Carlson 72 and 83-85. The assumption of early modern mountain gloom is taken as a given in the introduction and several of the chapters of Besson e.g. xxi, whilst Isserman and Weaver termed Nicolson's work 'the classic and still indispensable study of the origins of the mountain aesthetic' (457, c.f. 27).

2 One of the first to do so was Janice Hewlett Koelb, who particularly critiqued Nicolson's suggestion that the Christian and Roman traditions presented an innately negative view of mountains.
} 
for example in proposing that positive mountain attitudes appeared earlier than she suggested - without challenging the sense of a dichotomous change (Korenjak; Barton). More recent, and in some cases nascent, work has sought to argue generally against any perception of premodern "mountain gloom", pointing towards evidence for more positive and nuanced engagement with mountains from the classical, medieval, and early modern eras (König; Hollis). ${ }^{3}$ However, there is no doubt that the basic concept has limited the last six decades of research into premodern mountain experiences. After all, the traditional narrative suggests that not only did premodern Europeans fear mountains, they also avoided them at all costs. Why study an absence of enjoyment of, and engagement with, mountains when the centuries of modern "mountain glory" offer such rich pickings? ${ }^{4}$

Moreover, even the occasional gloom-critical voice is drowned out by the widespread acceptance of the idea, both within and without academia. The concept of mountain gloom and mountain glory is more than just an academic theory: it has attained the status of general historical knowledge. Ten years after the publication of Nicolson's monograph, the art historian Kenneth Clark confidently told the audience of his documentary series Civilisation that "For over two thousand years mountains had been considered simply a nuisance: unproductive, obstacles

3 See also preliminary work by Anthony Bale on mountains and pilgrimage in medieval Europe. blogs.bbk.ac.uk/research/tag/holy-land/. Accessed 14.03.2018).

4 See, for example, Di Palma, who identifies mountains in the early modern period as objects of disgust, and suggests that 'great lacunae exist in terms of verbal and visual representations' of such landscapes, since 'Lingering in order to pen an extended description or to delineate a view was simply out of the question when the goal was to put as much space between one's self and the offending environment as quickly as possible' (10-11). 
to communication, the refuge of bandits and heretics" (episode 11). In January 2018, readers of an article protesting the application of new rules requiring a minimal level of mountaineering equipment for those wishing to climb Mont Blanc read that before the middle of the nineteenth century, mountains were "seen as landscapes of evil otherness, where the tempestuous gods exercised their wrath. The curious ventured not" (Sanzaro). The concept is present in many works - both of academic research and popular mountaineering history or literature - without direct reference to Nicolson (Ring, 7-13; Black, 3). 5

This is not necessarily a symptom of poor standards of referencing, but is rather emblematic of the fact that the concept of mountain gloom and mountain glory as it currently stands has gone beyond the monograph which gave it so compelling a catch-phrase. The idea is one which has come to be so taken for granted that a formal citation is now unnecessary. However - as Nicolson herself acknowledged - the idea also dates to before her 1959 monograph. She did not open Mountain Gloom and Mountain Glory with the claim that she was laying out a new argument, but rather exploring the pre-existing, and uncontested idea that mountain attitudes underwent an almost complete reversal between premodernity and modernity.

\footnotetext{
5 The idea of mountain gloom and mountain glory has most prominently been brought into the public eye in recent years in Robert Macfarlane's highly successful Mountains of the Mind, in which he asserted that 'The notion barely existed... that wild landscape might hold any sort of appeal' (14). His second chapter, 'The Great Stone Book', dealing with Thomas Burnet and how developments in geology impacted attitudes towards mountains, is heavily indebted to Nicolson's Mountain Gloom and Mountain Glory. Macfarlane's articulation of mountain gloom has been further amplified by its inclusion in a recent documentary, for which he was co-author ('Mountain', dir. Jennifer Peedom).
} 
This article will therefore trace the "genealogy" of Nicolson's assumption, and in so doing will demonstrate that the concept of mountain gloom and glory tells us more about the modern contexts in which it developed than the premodern ones which it purports to describe. It will argue that prominent, pre-Nicolsonian articulations of this shift in attitudes - including articulations which she cited as laying out the 'basic problem' which she sought to solve - were not neutral analyses of history. ${ }^{6}$ Instead, they were deeply implicated within discourses of modern exceptionalism, functioning in two key areas: in the construction of ideas of Romanticism and post-Romantic literary criticism, and in the community-forming narratives of the self-declared 'first mountaineers' of the Alpine Club. ${ }^{7}$

\section{The Literary Heritage}

It is perhaps surprising that one of the earliest expressions of the concept of premodern "mountain gloom" giving way to modern "glory" can be found in a peculiar document in which one of the forefathers of Romanticism pitted himself against the social politics of the expansion of railways. The figure of William Wordsworth (1770-1850), the famous inhabitant of Dove Cottage, scarcely needs introduction, but pertinent to this article is the preface he wrote to the 1800 edition of his and Samuel Taylor Coleridge's Lyrical Ballads, in which he asserted the new and extraordinary nature of the poetic project upon which the pair were engaged. Their poems, which emanated from "the spontaneous overflow of powerful feelings", represented "a class of

\footnotetext{
${ }^{6}$ Insert footnote r.e. Nicolson pointing to her sources here.

7 By this, I mean the British Alpine Club: however, first of its type to be founded as it was, it has always been 'the' Alpine Club: national or regional modifiers apply only to those which have followed it.
} 
Poetry... adapted to interest mankind permanently", and required an explanatory preface precisely because they were "so materially different from those, upon which general approbation is at present bestowed" (Lyrical Ballads, vol. 1, xxxiii-xxxiv and vii). Forty-four years later, an elderly Wordsworth would again invoke the theme of originality in order to challenge a proposal for the construction of a new railway into the Lake District via Kendal, with a branch striking deep into the heart of the area to Windermere. ${ }^{8} \mathrm{~A}$ key feature of his argument against the railway - and the inevitable influx of town-based visitors which it would augur - rested upon his assertion that "the relish for choice and picturesque natural scenery... is of quite recent origin" (Prose Works, 326-327).

Why did Wordsworth turn to the past in order to object to something due to happen in the future? Arguments in favour of the railway hung on the question of democracy of access: of the potential of this new form of transportation to enable more and less affluent people to visit the picturesque scenery of the Lake District. In his emphatic letter, addressed to the editor of the Morning Post newspaper, Wordsworth suggested that this was a fallacy; not only were there already railways and other forms of transport running into the Lakes, but the assertion that "the poor" (Wordsworth's term) required greater levels of access rested upon the assumption that they would enjoy such access. Or, as Wordsworth put it, "The wrong [of objecting], if any, must lie in the unwarrantable obstruction of an attainable benefit" (326). He argued that there was, in fact, no such evidence for the universal attainability of the "benefit" of taking pleasure from mountainscapes.

\footnotetext{
8 For Wordsworth's objections in the context of increasing railway travel and tourism, see Prickett.
} 
Wordsworth demonstrated this first by reference to the past, presenting his reader with a gallery of seventeenth-century characters whom he judged to have demonstrated little or no positive feeling towards mountains. These included the naturalist John Ray (1627-1705), who according to Wordsworth was "silent upon the sublimity and beauty" of the Alps, and the diarist John Evelyn (1620-1706), who only "dilates upon the terrible, the melancholy, and the uncomfortable" (327). ${ }^{9}$ Wordsworth acknowledged that Thomas Burnet (c.1635-1715) - one of the central figures of Marjorie Hope Nicolson's 1959 monograph - offered a worthy description of the "magnificent appearances" of the mountains, but with this exception insisted that, until the late eighteenth century,

there is not... a single traveller whose published writings disprove the assertion that, where precipitous rocks and mountains are mentioned at all, they are spoken of as objects of dislike and fear, not of admiration. (327)

According to Wordsworth, a shift towards a new, more positive attitude, was only marked in

\footnotetext{
9 John Ray may have been silent upon the Alps, but he expressed great exasperation when a local guide refused to brave foul weather to lead him up Snowdon in Wales, and expressed appreciation for how much more 'pleasant to behold' a hilly landscape was than a flat one (Select Remains, 125-126, and Miscelleaneous Discourses, 165-166). John Evelyn ascended the Simplon Pass $(2,005 \mathrm{~m})$ in 1646 in poor weather conditions, resulting in the near-loss of a baggage pony which slipped from the path and the panic of his group's guide, and his account is accordingly grim; it should be noted, however, that at the summit of Mount Amiata $(1,738 \mathrm{~m})$ in 1644 Evelyn had stared out at the clouds 'rowling under our feete' and found the summit view to be 'one of the most pleasant' sights he had ever beheld (vol. ii, 508515 and 207-208).
} 
1741 by the "noble strain" with which "the Poet Gray" (i.e. Thomas Gray, 1716-1771) composed a Neo-Latin ode upon the Grand Chartreuse. With this brief historical overview, then, William Wordsworth sketched one of the earliest articulations of the narrative of mountain gloom and glory.

The reader might well be wondering the same question which Wordsworth posed in his rhetorical transition from past landscape travels to future transport routes: "But what has all this to do with the subject?" The crux of the matter lay in the fact that from Wordsworth's vantage point, "mountain glory" - recent development as it was - was not yet a universal taste. His historical digression was designed "to show that a vivid perception of romantic scenery is neither inherent in mankind, nor a necessary consequence of even a comprehensive education". The type of landscape boasted by the Lake District, indeed, "cannot... be comprehended, or even very imperfectly conceived, without processes of culture or opportunities of observation in some degree habitual". The unhabituated mind, then - as allegedly demonstrated in Wordsworth's seventeenth-century examples - would not only fail to gain pleasure "from the sight of common beauty, but will even turn it into an object of disgust" (328). It was for this reason that Wordsworth thought it not only useless, but actively damaging to bring the "imperfectly educated classes" to the shores of Lake Windermere; they would be unprepared to appreciate its wilderness or tranquility, and in seeking lower pleasures such as beer-houses or boat races, would ultimately lead to the destruction of the same (331-332).

For William Wordsworth, the appreciation of mountain scenery was a matter of taste, and taste 
was something which had to be learned and developed. It was also a taste which - though he, as the self-appointed defender of sublime scenery, evidently possessed - was absent in the makeup of both early modern travellers to the Alps and of the unlettered masses of the mid-nineteenth century. Wordsworth does not go so far as to state it explicitly, but the underlying message is there: the same author who went to such efforts to emphasise his exceptional form of poetic vision in the preface to the Lyrical Ballads likewise asserted, however unconsciously, his social and historical exceptionalism in the case of mountain taste in his letter to the Morning Post.

Wordsworth was most likely deeply displeased when the railway opened in 1847 despite his protests. He would perhaps have been comforted, however, to know that his implicit claim of primacy in the field of natural taste was accepted with relatively little question by later nineteenth-century literary critics and inheritors of the Romantic tradition. In his 1877 On Poetic Interpretation of Nature, J.C. Shairp, Professor of Poetry at Oxford, identified Wordsworth as the "Interpreter of Nature" at the pinnacle of a gradual, modern ascent towards landscape appreciation in English literature. Shairp's volume also reveals a characteristic which is inherent to the literary side of the genealogy of mountain gloom and glory: namely, the significance placed on the writings and perceptions of certain great, 'canonical' individuals. ${ }^{10}$ Shairp, considering the absence of mountains in the writings of Shakespeare, mused that

it is certain that the power of mountains is not expressed in that poetry which expresses

\footnotetext{
${ }^{10}$ For canon-building in a general perspective, see Gorak. For a specific illustration of the misleading influence of canonicity, see Jackson Williams.
} 
almost every other conceivable thing, and that the mountain rapture had to lie dumb for two more centuries before it found utterance in English song. (170)

In essence, if the most canonical of early modern English authors did not mention mountains, no one of his era could possibly have appreciated them. Shakespeare's mountain silence naturally represented wholesale premodern mountain gloom.

The warping effect of canon-building can also be seen in various attempts to chart the precise beginnings of modern 'mountain glory', with numerous critics and scholars seeking to ascribe the honour of being 'the first' to recognise or experience it to their chosen canonical figures. Alfred Biese, considering The Development of Feeling for Nature (first published in German in 1888), wrote of "The Awakening of Feeling for the Romantic", explicitly equating "mountain feeling" with "the Romantic". Before Romanticism, "There were no outbursts of admiration at sight of the great snow-peaks; 'horrible' and 'dreadful' were the current epithets" (262-263). Biese acknowledged a few exceptions, but, nevertheless, "It was Rousseau" - hero of the Enlightenment - "who first discovered that the Alps were beautiful", and who "was the real exponent of rapture for the high Alps and romantic scenery in general" (261 and 266). Edmund W. Gosse, in an 1882 biography of the poet Thomas Gray, unsurprisingly identified his subject as "the first of the romantic lovers of nature", preceding Rousseau, and in contrast with his travelling companion Horace Walpole, whose "remarks about the horrors of Alpine travelling do indeed savour of the old-fashioned fear of what was sublime in nature" (32-33). 
By 1917, the inauguration date of the "Return to Nature in English poetry" had been pushed back to the early eighteenth century, with Cecil Moore identifying the figure of Anthony Ashley Cooper, $3^{\text {rd }}$ Earl of Shaftesbury (1671-1713) as "a pioneer" who "was not unaware that he was promulgating an æsthetic view at variance with the literary creed of his time". Still, Shaftesbury's appreciation of mountain glory was not fully realized; it was a foreshadowing, as much as anything else, of "the perfected creed of Wordsworth" (265-267). ${ }^{11}$ In 1928, P.K. Das would argue for an earlier start-date yet, suggesting that "The Earliest Expression of Delight in Mountains in the Poetry of the Eighteenth Century" had occurred, in fact, as early as it possibly could do without breaking the barrier of the seventeenth century, in the form of Joseph Addison's 1701 Letter from Italy (215-216). This labelling of Addison as "the first" mountain lover was repeated in 1935 by Clarence de Witt Thorpe, though he offered up John Dennis, and his 1688 visit to the Alps, as a yet earlier voice of the modern feeling for wild nature (464-482).

What is notable about these later examples is that by the start of the twentieth century, the essential fact that there had been a shift - whether expressed as a return to nature, a voicing of mountain rapture, or a feeling for the Romantic - in attitudes towards mountains was absolutely taken for granted. What debate there was focussed on whether to backdate the timing of this shift by a matter of decades in order to ascribe the first expression of it to one canonical author or another. Literary articulations of the idea of mountain gloom and glory where therefore

\footnotetext{
11 Moore's article - in common with many of the literary writings considered here - was cited by Nicolson in her overview of the scholarly background to the 'basic problem in the history of taste', and she deemed it a 'classic, the first significant treatment of the mountain problem and a fundamental contribution to the study of the whole naturalistic movement in eighteenth-century literature' (Mountain Gloom, 21).
} 
largely expressed in the service of identifying particular individuals as being the first to view mountains in a certain way. Doing so with reference to key figures of literary history - Rousseau, Wordsworth, Gray - served several related purposes. First, and in a circular fashion, the assertion of their recognition of mountain glory emphasised their importance and right to canonicity as 'modern' authors. At the same time, turning to the work of key writers also served to further embed the idea of a stark shift in mountain attitudes; as Shairp put it, if Shakespeare did not adore mountains whilst Wordsworth did, a reversal of general taste for landscape must have occurred in the interim. Finally, as is seen most clearly in the example of Wordsworth's letter to the Morning Post, articulations of modern-day mountain glory could also serve to assert a sense of superiority or distinction from those who did not or could not see mountains in the same light. William Wordsworth belonged among the mountains; premoderns and the modern poor alike did not.

\section{The Mountaineering Story}

The mountaineering side of the genealogy of mountain gloom and glory shares many features with the literary one. Just as Wordsworth, a grandfather of Romanticism, put forward his version of the narrative, so too did some of the earliest inaugurators of modern mountaineering delineate theirs. One of the most expansive texts to tell the story of mountain attitudes with specific reference to modern mountaineering was Leslie Stephen's "The Love of Mountain Scenery", the essay with which he opened the first edition of his Playground of Europe (1871). 
Stephen was the fourth president of the Alpine Club, and his Playground is one of the most prominent works of mountaineering literature to come out of "the golden age" of alpinism. His essay opens with an anecdote which draws a markedly similar connection between mountain attitudes and socioeconomic class as was evident in Wordsworth's protest against the railways. Sitting on a train leaving London with "A highly intelligent Swiss guide", Stephen reports that he commented to his companion that the view wasn't as fine as that which the pair had shared from the top of Mont Blanc.

"Ah, sir!" was his pathetic reply, "it is far finer!" This frank avowal set me thinking. Were my most cherished prejudices folly, or was my favourite guide a fool? A question not to be asked! Yet very similar shocks, as has often been remarked, await the student of early Alpine literature. (1)

From this opening, Stephen went on to detail the shift from past to present mountain attitudes under two headings very nearly as catchy as Nicolson's borrowed "Mountain Gloom" and "Mountain Glory", as he elucidated "The Old School" of mountain superstition and distaste, and how it gave way to "The New School" of modern mountaineering and mountain appreciation. ${ }^{12}$

12 The titular dichotomy of Nicolson's monograph, which I have taken in this article as a convenient shorthand for the basic concept it represents, was originally drawn from John Ruskin's Modern Painters (Works of John Ruskin, vol. 6, 385-466). Ironically, 'The Mountain Gloom' and 'The Mountain Glory' essays are not especially significant as historical constructions of the idea that took their name. They reverse Wordsworth's approach: the poet utilised past contexts to illustrate the level of non-elite mountain taste while Ruskin's focus was on the grim mountain experiences of Swiss peasants, which he vaguely implied were in common with past attitudes. 
Stephen's general summary of the "Old School" was that "before the turning-point of the eighteenth century a civilised being might, if he pleased, regard the Alps with unmitigated horror" (41-42), and proffered various examples to support this statement. Exhibit one was a 1713 volume which he deemed poorly-named: Abraham Ruchat's Délices de la Suisse (The Delights of Switzerland), which Stephen gently mocked for its emphasis upon "the number of cheeses produced in Alpine dairies and the quantity of chamois leather and crystals which may be obtained in mountain fastnesses". Such a focus on the utility of mountains struck Stephen as akin to "a sea-sick traveller" who hates the ocean, "though he may feebly remind himself that it is a good place to fish" (1-4). Joseph Addison - one of the heroes of the later literary narrative of mountain glory - is found wanting in the "painful degree of disrespect" with which he wrote of Lake Geneva, later deemed "almost a sacred place to the lover of mountain scenery" (4-6). Bishop Gilbert Burnet is cited as having famously "glanced at the mountains with considerable disgust", whilst the historian Edward Gibbon represents only the slightest progress, admiring the mountains as he did "from a safe distance", rather than up close and personal (6).

Stephen's consciously witty catalogue of past attitudes reaches a pinnacle with his commentary upon Samuel Johnson's derogatory attitude towards the Scottish Highlands, a "single-minded abhorrence" expressed some time after it had apparently become expected to enter into transports at the sight of rugged hills. Stephen wryly excuses the corpulent Johnson on individual grounds ("It would be difficult to imagine a human being more thoroughly out of his element than Dr. Johnson on a mountain"), but also on generic ones: 
We may pardon them [Johnson and other gloomy mountain writers] for expressing frankly sentiments which a considerable number of modern tourists might probably discover at the bottom of their hearts. Indeed, there is a good deal to be said for their opinions. Is there not something rather unnatural in the modern enthusiasm, or affectation of enthusiasm, for "uniformity of barrenness"? (8-10)

With this reflection, Stephen turned the "problem" that Nicolson would later grapple with on its head: the question, he suggested, was not so much one of why early modern people disliked mountains, but rather why modern Europeans should love them so (11).

In seeking to answer this, Stephen rejected a longstanding theory which proposed that the key difference between the premodern mountain experience and the modern was an increase in "comfort and security" for upland travellers - such as better roads, and fewer (supposed) bandits (10-12).13 The shift, he argued - following Wordsworth - was not one of changing circumstances but rather of the development of taste:

The mountains, like music, require not only the absence of disturbing causes, but the presence of a delicate and cultivated taste. Early travellers might perceive the same

\footnotetext{
13 Stephen referenced Macaulay, whose History of England (vol. 3, 283-247) considered the apparent change in attitude towards the landscape (and peoples) of the Scottish Highlands. References to bandits (often feared, but rarely encountered) on premodern mountain roads are a frequent and long-established trope.
} 
objects with their outward sense; but they were affected as a thoroughly unmusical person is affected by the notes of some complex harmony, as a chaos of unmeaning sounds. (13-14)

In essence, Stephen's assertion was that what the nineteenth century possessed that the preceding centuries did not, was an ear for mountains.

Stephen did admit some exceptions to the rule of premodern mountain distaste. For example, he acknowledged that "even in those dark ages", some "men of science... surmounted their natural terror or disgust" in order to investigate the mountain landscape, whether out of botanical or geological interest. He noted that such scientists - including the seventeenthcentury Jesuit Athanasius Kircher, and the Swiss naturalist Johann Jakob Scheuchzer - hinted at the existence of folk superstitions relating to mountains (15-20), which Stephen suggested could almost be viewed as analogous to modern feelings of wonder and awe:

Old travellers saw a mountain and called it simply a hideous excrescence; but then they peopled it with monsters and demons... mysterious voices spoke in its avalanches; dragons winged their way across its gorges... Was this not merely expressing in another way the same sense of awe which we describe by calling the mountain itself sublime and beautiful? (21)

Nevertheless, this superstitious appreciation sat in contrast with the enlightened awe gained in 
the late eighteenth century when scientists developed a theory of deep geological time, allowing not just naturalists, but also travellers and poets, to find their "imaginations... awed when we look at mountains... as monuments of the slow working of stupendous forces of nature through countless millenniums" (32-34).

Unique to the late eighteenth and nineteenth centuries, then, was a scientific understanding of mountains combined with a poetic - indeed, Romantic - articulation of them which served to inaugurate what Stephen called the "New School", and what Nicolson would call "mountain glory". In the second half of his essay, Stephen sought to locate the precise moment at which "the taste for mountain scenery" became "a recognised and vigorous reality". He emphasised that the development of this taste took time. Once again echoing Wordsworth, he insisted that

a Frenchman on his first visit to Chamouni did not appreciate the size of the objects before him. Nothing could be more natural, for the simple reason that mountains, like all other superlatively beautiful objects, require long and affectionate study before their charms are fully revealed. The cockney who enters the British Museum generally prefers the stuffed hippopotamus to the Elgin marbles; but that is not the fault of the Greek sculptors. (35-36)

It was not, Stephen asserted, until 1760 that "The dividing line may be drawn" - i.e. the first journey of Horace Benedict de Saussure into Chamonix. Saussure was a Genevan meteorologist whose offer of a reward to the first person to ascend the summit of Mont Blanc arguably opened 
up the path that would lead to the modern sport of mountaineering. However, he was a mere accomplice compared to Rousseau, whom Stephen defined as "the Columbus of the Alps, or the Luther of the new creed of mountain worship". As far as Stephen was concerned, "If Rousseau were tried for the crime of setting up mountains as objects of human worship, he would be convicted by any impartial jury" (38-39). ${ }^{14}$ After this point, the appreciation of mountain glory became the accepted cultural mode, and "It required as much originality to dislike as it had previously required to admire" (41-42).

The conclusion to Stephen's essay - which, significantly, represented the introductory chapter to a volume relating his various adventures in the Alps over the preceding decades - leaves the reader in no doubt as to the significance which he attached to the modern love of mountain scenery. This can be illustrated most clearly with reference to two substantial passages:

My readers - for I may assume that my readers are mountain-lovers - will agree that the love of mountains is intimately connected with all that is noblest in human nature [...] Mountain scenery is the antithesis not so much of the plains as of the commonplace. (6566)

14 Both a mountaineer and literary scholar, Leslie Stephen offers a key example of miscegenation between the two strands of the genealogy of mountain gloom and glory drawn in this article. He delivered the 1903 Ford Lectures in British History, focussing on the history of English literature, incorporating reflections on the shifting attitudes towards nature, emphasising the endpoint of the 'true Rousseau version of Nature worship' (English Literature and Society in the Eighteenth Century, 120-138). 
Meanwhile it should be - I can hardly say it is - the purpose of the following pages to prove that whilst all good and wise men necessarily love the mountains, those love them best who have wandered longest in their recesses, and have most endangered their own lives and those of their guides in the attempt to open out routes amongst them. (68)

In a nutshell, Stephen's assertion - made far more explicit than Wordsworth's - was that the appreciation of mountains represented not only a developed taste but also a moral advancement: "the love of mountains is intimately connected with all that is noblest in human nature". And who was it who loved the mountains most? Those "who have wandered longest in their recesses". Stephen did not, of course, mean by this the local inhabitants of Alpine villages: rather, he referred to the members of the British Alpine Club, for whom the Alpine space was a "playground" to be explored and conquered.

I therefore propose that Stephen's essay represented an attempt (which has proved remarkably successful) to claim for modern mountaineering the "summit position" of mountain appreciation. The concept of the summit position has been articulated by Peter Hansen as the vision of "an autonomous individual... first on a hitherto untrodden peak" (2). This article posits that the summit position was central not just to the development of mountaineering as an activity but also to the way that early mountaineers devised the origin story and "prehistory" of their sport. ${ }^{15}$

\footnotetext{
15 For the purposes of this article, it is fortunate that mountaineering - which has been called 'the most literary of all sports' - developed these stories within the pages of books and journal articles. Some such articles were, indeed, self-
} 
In the first instance, these stories were largely told within the context of the Alpine Club and its publications. The Alpine Journal was first published in 1863 and numerous notes, reviews, and articles published in its first decades saw late-nineteenth-century mountaineers looking back on the then-short history of their sport, considering what preceded it, and seeking to define what made it extraordinary - quite regularly by way of contrast, just as Wordsworth employed, with the premodern past. This strident sense of exceptionalism is particularly explicit in a review made of a volume of travel literature, Andrew Wilson's The Abode of Snow: Observations on a Journal from Chinese Tibet to the Indian Caucasus through the Upper Valleys of the Himalaya (1875). The anonymous reviewer reserved their greatest ire not for the book itself, but for another review of the same volume:

According to "The Times", this volume is a record of "systematic mountaineering," such as is seldom undertaken or described by members of the Alpine Club. We are sorry to see

conscious of the constructed nature of mountaineering's 'firsts': one tongue-in-cheek piece surveys the modern metric by which a single mountain could 'be the means of bringing glory and honour to many climbers', including the first recorded ascent, the first ascent from the other side, the first ascent by a certain nationality, or the first ascent without guides. The author insightfully and acerbically notes that 'We have found it, long since, necessary to look upon ascents made by chamois hunters as counting for nothing' (Dent, 'Mountaineering in the Old Style', 393-394). The literary nature of mountaineering as a pursuit is such that it has had an entire book-length bibliography dedicated to it, in multiple editions: see Neate. Throughout this article, 'mountaineering literature' refers to writings about mountaineering written by mountaineers - although it is worth informally noting that, even today, the majority of writers (both popular and academic) working on the contemporary or historical aspects of mountain climbing are generally mountaineers or mountain enthusiasts themselves. For the awkward experience of a non-climbing historian seeking to write about mountaineering, see Gilchrist, 231. 
the leading journal expose both its complete ignorance of the subject it is talking about, and of the meaning of the words it uses. As we understand the word - and its introducers have perhaps the best right to define its meaning - Mr. Wilson's book is not a record of "mountaineering" at all. It is the story of a journey made, with but one or two exceptions of a few miles, on horseback or on a litter. This kind of mountain travel was the only sort known to our ancestors. The modern passion for foot-climbing as an athletic sport was felt to be so distinct that a new word "mountaineering," had to be invented for it. (338)

Reading this passage against the concluding lines of Leslie Stephen's essay on "The Love of Mountain Scenery", one finds an impossible bar set by nineteenth-century mountaineers for any potential predecessors. "Mountaineering" is a term to be defined solely by mountaineers (despite the fact that very many "mountaineers", i.e. mountain people, lived and travelled amidst the peaks before they did), and, as Stephens suggested, is the truest expression of the love of mountains. ${ }^{16}$ Meanwhile, "our ancestors", by virtue of sullying their foot-climbs with the use of horses, never participated in mountaineering so strictly defined. A later, twentiethcentury history of mountaineering would put this point even more explicitly, emphasising that "utilitarian" reasons for climbing mountains - whether for the pursuit of fame, science, or wealth - were distinctive from mountaineering as a "disinterested activity" pursued for purely "aesthetic" considerations (Frison-Roches and Jouty, 8-10). Mountaineering (and thus the love of mountains) was defined against the very methods and motivations which had taken most people in human history up mountains.

16 For the appropriation of the term 'mountaineer', c.f. Debarbieux and Rudaz, 108. 
The prehistory of mountain-climbing formed the subject - either partial or whole - of several presidential addresses delivered to the members of the Alpine Club. C.E. Mathews, in 1880, added to assertions of temporal exceptionalism a nationalist colour. He asserted proudly of his fellow club members that "We are making Alpine history with extraordinary rapidity [...] Yet the prehistoric epoch was not so long ago". Mathews, indeed, defined the "earliest infancy" of mountaineering as 1855 , when JD Forbes, glaciologist and climber, visited Zermatt. Such a declaration might be surprising to those who took or take the first ascent of Mont Blanc, in 1786, as the inauguration of modern mountaineering, but Mathews dismissed this: "that expedition [up Mont Blanc] is not necessarily mountaineering. The men who practised climbing for its own sake were so few that they might be counted on the fingers of one hand" (252). He swiftly elaborated that "The original founders of the [Alpine] Club gained their Alpine laurels between 1854 and $1859^{\prime \prime}$, and the remainder of his lecture is given over to assertions of the extraordinary achievements of the English man. He crowed over the fact that, though they lived relatively far from them, "the English" had been "the first to carry off the honours" of the Alps, with other nations left only "to follow our example" (253-254; JD Forbes's Scottishness was quietly elided over). This account makes explicit a sleight of hand which is at work in many of the above stories of the mountain past: by defining mountain appreciation, or mountain climbing, in very narrow terms, the author could firmly claim the summit position for their chosen victor. In this case, Mathews placed on the summit English heroism, the Alpine Club itself, and the "first" mountaineers in whose footsteps he and his fellow-members were very closely following. 
Another familiar tic can be found in the account given by an earlier Alpine Club president, William Longman, of "Modern Mountaineering and the History of the Alpine Club", and that is the selective adoption of key "exceptional" figures from pre-mountaineering history who broke the accepted rule of mountain gloom. Although Longman claimed he had no desire either to delve into antiquity or to rival the "admirable account" given in Stephen's Playground, he could not resist including "some account of the ascents of European mountains before the first members of our club began to climb, and thus gradually to arrive at the remarkable development of the passion for mountain climbing" in evidence in the present day (1). He considered "early" ascents and mountain writings relating to various regions, but gave particular prominence to the Swiss Alps. He credited the foundation of the University of Basel in 1460 as lending "the first impulse to mountain literature by bringing men of awakened minds into close and constant neighbourhood with mountains" (40): note the echo, here, between the "awakened minds" necessary to appreciate mountains and "all that is noblest in human nature" seen reflected in the love of mountains by Stephens.

Longman was dismissive of early sixteenth-century authors such as Heinrich Moriti of Glarus, who "In 1514 composed one of the first works on the Alps, a poem in Latin hexameters, the general dullness of which is only here and there relieved by a few graceful lines". He gave greater credit, however, to Conrad Gesner (1516-1565), who in 1543 declared his determination to climb a new mountain every year. Gesner's enthusiasm led Longman to declare that "The mountain passion was even then alive, smouldering on in the hearts of a few Swiss students for two centuries before it burst out in Savoy into the blaze which has now spread across Europe" (40). 
Crucially, however, these were only "a few", and it was not until the eighteenth century that "the eloquent voice of... Rousseau" was "accepted as the interpreter of feelings towards nature which must have been gathering for some time in order to obtain for their preacher such swift and general acceptance" (45). If Longman permitted premodern men honorary membership, as it were, of the Alpine Club, this was only because they represented the beginning of the teleology of which Romanticism and modern mountaineering formed the pinnacle.

Two years later, the general public would gain an insight into the history of mountaineering - at least, the mountaineers' version of the history of mountaineering - in the form of the 1892 Mountaineering volume of the Badminton Library of Sports and Pastimes, edited by C.T. Dent, and with an opening chapter on "The Early History of Mountaineering" written by Sir Frederick Pollock. An English jurist, author of the History of English Law alongside F.W. Maitland, and first librarian of the Alpine Club, Pollock outdid himself with a thirty-eight-page essay, complete with footnotes and commentary upon different available translations of primary sources. He opened with a by-now familiar definition of mountaineering as standing in contrast to mere "mountain travelling". According to Pollock, a "traveller who goes among mountains because that is the only way for him to attain some further object, or the least inconvenient way, may possibly become a mountaineer in the course of his journey, but he is not one when he begins it". Indeed, one could only truly become a mountaineer when they could say of their exploits, labor ipse voluptas - "labour is pleasure" (1-2). Historically speaking, this led Pollock to the firm declaration that 
The history of mountaineering proper has no direct concern with the journeys undertaken during the last twenty centuries or more by the people, famous or obscure, warriors, pilgrims, or travellers... who crossed the Alps because they stood in the way, and would have been better pleased had there not been Alps to cross. (2)

From this point of view, "the continuous history of mountaineering can be carried back only a few generations" - or, echoing Mathews, to around 1850, by which point climbing Mont Blanc was no longer seen as an "astonishing feat". In other words, the "modern period of mountaineering" began with the Alpine Club (4-5).

Nevertheless, the Club librarian could not help but be aware of earlier examples that certainly looked a lot like modern mountaineering. He therefore considered the qualifications of potential "precursors of the art", his criteria for approval being the proper motivation, sufficient level of physical mountain activity undertaken, and the expression of enjoyment. Pollock disdained Petrarch and his ascent of Mont Ventoux, for example, for though he apparently climbed to see the view, "there is nothing to show that he enjoyed the walk" (7). Meanwhile, though Dante apparently displayed "much more of a climber's feelings and observations", Pollock could find no evidence that he undertook "any very high or remote excursion" (7). However, Leonardo da Vinci, "one of the most extraordinary men of any time", was allowed into the club of mountain appreciation, since his "drawings show an admirable sense of mountain form", and evidence could be found for his physical presence on high mountain-tops (8). Pollock's greatest praise, however, was reserved for the Swiss humanist who had caught Longman's attention: the 
ubiquitous Conrad Gesner, alongside his countryman Josias Simler, who both "studied and visited the mountains in the truest mountaineering spirit" (9). Pollock argued that Simler's writings - incorporating "sound practical advice... as to the precautions to be adopted above the snowline" - following so closely on from Gesner's joyous mountain expeditions, indicated that "a native Swiss school of mountaineering, with exactly the aims and the spirit of the modern mountaineers, was on the point of being formed by the scholars of Zürich" (17). ${ }^{17}$ This development was arrested, according to Pollock, by the civil and religious disruptions of the seventeenth century, leading to a "barren period" of many decades, which would finally be broken by Rousseau - although Pollock took care to point out that "among Englishmen", Thomas Gray was ahead of his time in delighting in mountain scenery $(18,22)$.

Pollock's account - one of the denser articulations of mountaineering's pre-history, in spite of its popular packaging - is significant in a number of ways. Uniquely, it hinted at the idea that the nineteenth-century inauguration of modern mountaineering was a historically contingent event that, but for the chance happenstance of the Reformation and its ensuing disturbances, could have occurred two hundred years earlier. In other words, he was at the very least comfortable with the thought that the Alpine Club might share their summit position as mountain pioneers with a select few premodern climbers. It is significant that the three individuals whom he allowed as genuine precursors to the modern mountain sentiment included one - Da Vinci - a legendary

\footnotetext{
17 Simler's discussion of the Alpine landscape, its dangers, and how to avoid them, can be found in Simler, Vallesiae descriptio (1574), with an extracted translation in Simler, 'Vallesiae et Alpinum descriptio', trans. and ed. Alan Weber, (2003), 22-28.
} 
genius, and two - Gesner and Simler - who had long been viewed as honorary mountaineers by the modern exponents of the sport. They were, arguably, the only individuals to whom such laurels could be given; even Petrarch was not deemed worthy. Even whilst embracing a select few "precursors", the exclusivity of the narrative of modern mountaineering held true.

The Badminton Library Mountaineering volume was followed in quick succession in 1893 by a sibling in the All-England Series, written by Claude Wilson. It treated the history of mountaineering in a mere four pages, two of which took it from Biblical times up to the foundation of the Alpine Club. To the break between premodern and modern activities it dedicated but two sentences: one which commented that "ancient and classical literatures" made reference only to "utilitarian ascents", and another which stated simply that "The earliest record of mountaineering for the love of the thing is only four hundred years old; and it was not until the latter half of the present century that the pursuit made any real headway" (6-7). If this was not condensed enough, three decades later the first chapter of the Mountaineering volume of the Lonsdale Library of Sports, Games \& Pastimes (1934) would open with the straightforward assertion that "it is common knowledge that mountains were once regarded as things of terror and horror" (17). By the 1930s, then, the narrative of mountain gloom and glory - though Marjorie Hope Nicolson had yet to give it that name - was fully embedded in mountaineering literature and in the wider consciousness of its readers. ${ }^{18}$

\footnotetext{
18 It is worth observing that canonicity, broadly construed, is clearly at play here in the acknowledgement of exceptions just as it was in the establishment of the rule. Shakespeare, whose lack of mountain utterance was taken by literary critics as the epitome of mountain gloom, helped form the rule, whilst his equally significant peers (Dante, Da Vinci) who apparently expressed mountain glory are acknowledged as the exceptions which prove it.
} 


\section{Conclusion}

It is these two strands - the literary heritage, and the mountaineering story - which underlie Nicolson's "basic problem in the history of taste", and which created the idea to which she gave such a compelling title. It is important to emphasise that the purpose of this article has not been to denigrate the quality of Nicolson's work or the importance of her contribution. Her methodology - conducting a literary analysis of natural philosophical texts, and reading them alongside "non-scientific" works of poetry and theology - was ahead of its time and arguably paved the way for important developments in the history of science. Many of the observations made within Mountain Gloom and Mountain Glory (particularly those signaled by the oftforgotten subtitle of her work, in which she articulated sublimity as "the aesthetics of the infinite") are significant and insightful. The longevity of the monograph's popularity, though partly a function of its identity as a reliable scholarly source for the concept of premodern mountain gloom, can also be credited as a testament to her clear, skillful, and eminently readable style. Mountain Gloom and Mountain Glory: The Development of the Aesthetics of the Infinite should be acknowledged as a remarkable contribution to mid-twentieth century historical and literary scholarship. However, acknowledging all of this does not necessitate accepting without question the basic idea for which the monograph has become so prominent an emblem. 
The concept of mountain gloom and glory is one that, today, sets barriers upon research into and understanding of premodern mountain engagements. The dichotomy is, when you look closely, an impossibly simplistic one, that can never hope to capture the full range and nuance of past responses to landscape. This much is evident in texts of mountaineering history, as early as Leslie Stephen's, which acknowledged the existence of premodern "exceptions" to the rule of mountain gloom. Instead, I would argue that it is time to set that rule aside.

This article could have taken the form of a survey of the many premodern sources that "disprove" mountain gloom, and there are two reasons why it did not. Firstly, to focus simply on "protesting too much" that premodern sources do not match the expectations of mountain gloom is to neglect the greater nuances of those sources, and to obviate the opportunity to approach them on their own terms. Neither premodern nor modern mountain engagements can be moulded to fit one side or other of a dichotomy which is essentially one of "negativity" giving way to "positivity". Constant and currently obligatory reference to the idea of the shift between mountain gloom and glory shackles understanding and analysis of both premodern and modern mountain responses. Secondly, I do not believe there is any justification for treating this dichotomous shift as an inevitable framework for research into mountain or landscape attitudes more generally. The foundational texts of the idea of mountain gloom and glory should not be read as objective explorations of historical realities. Instead, they were deeply embedded in the modern contexts in which they were written - and are, I argue, much more interesting and valuable when read as such. 
This article has therefore sought to negate the suggestion that the dichotomy of 'mountain gloom' and 'mountain glory' can be straightforwardly mapped on to the periodic divisions of 'premodernity' and 'modernity'. Not only does the dichotomy fail to fully represent the nuance, both positive and negative, of premodern mountain engagements, it also serves to oversimplify the nuance of modern-day engagements - both negative and positive. If 'mountain gloom' and 'mountain glory' exist at all then they exist alongside one another, in premodernity just as in modernity. This in turn suggests the compelling conclusion that the main temporal shift which this dichotomy enables us to map between the two periods is that modern, Western mountain enthusiasts were the first to presume that they were unique in recognising the glory of mountains.

Whether conscious or not, William Wordsworth, Leslie Stephen, and early members of the Alpine Club all had an agenda in articulating the idea that before them, few people enjoyed or loved mountains. The writings explored in this article are all variously implicated in discourses of canonicity, discourses of mountaineering, and above all in discourses of modernity. They all sought to assert a sense of exceptionalism, either belonging to an individual (whether that be Wordsworth, Rousseau, or Gray) or to a pursuit (mountaineering), and by extension to the modern era itself. These writings - for all that they have been filtered through generations of academic or mountaineering literature - are what underlie current-day narratives of the mountain past. This narrative asserts that Europeans hated mountains until they became Romantics, or until they became mountaineers. That Europeans hated mountains until they became modern. Such a narrative tells us more about modernity, about the mountaineering 
obsession with firsts, and about Romanticism's reification of originality, than it does about actual premodern contexts.

In the introduction of Mountain Gloom and Mountain Glory, Marjorie Hope Nicolson declared that "we see in Nature what we have been taught to see, we feel what we have been prepared to feel" (1). Almost two centuries after William Wordsworth penned his not-in-my-backyard letter to the Morning Post, the same is true of our understanding of the mountain past: we expect to see mountain gloom giving way to mountain glory, and that is what we find, regardless of the "exceptions" or distinctive historical contexts in which classical, medieval, or early modern accounts of mountain engagements have been penned. It is time to cease approaching these premodern sources with such expectations, and to let them instead speak for their complex, nuanced selves.

\section{Works Cited}

Anonymous, "Review of The Abode of Snow by Andrew Wilson (1875)." Alpine Journal. VII. (18741876): 338-342.

Barton, William M. Mountain Aesthetics in Early Modern Latin Literature. Oxford and New York: Routledge, 2017.

Besson, Françoise, ed. Mountains Figured and Disfigured in the English-Speaking World. Newcastle: Cambridge Scholars, 2010.

Biese, Alfred. The Development of the Feeling for Nature: In the Middle Ages and Modern Times. London: G. Routledge and Sons, Ltd., 1905 (first published in German 1888). 
Black, Jeremy. Italy and the Grand Tour. New Haven: Yale University Press, 2003.

Bourassa, Stephen C. The Aesthetics of Landscape. London and New York: Belhaven Press, 1991.

Brown, Graham T. "Early Mountaineering." Mountaineering. Ed. Sydney Spencer. London: Lonsdale Library, [1934].

Carlson, Allen. Aesthetics and the Environment: The Appreciation of Nature, Art, and Architecture. London and New York: Routledge, 2000.

Clark, Kenneth. "The Worship of Nature." Civilisation: A Personal View by Kenneth Clark. Episode 11. BBC, 1969.

Das, P.K. "The Earliest Expression of Delight in Mountains in the Poetry of the Eighteenth Century." The Modern Language Review. 23.2. (1928): 215-216.

Debarbieux, Bernard, and Rudaz, Gilles. The Mountain: A Political History from the Enlightenment to the Present. Trans. Jane Marie Todd. University of Chicago Press, 2015.

Dent, C.T. "Mountaineering in the Old Style," Alpine Journal. XI. (1882-1884): 382-394.

DeWitt Thorpe, Clarence. "Two Augustans Cross the Alps: Dennis and Addison on Mountain Scenery." Studies in Philology. 32.3. (1935): 464-482.

Di Palma, Vittoria. Wasteland: A History. New Haven: Yale University Press, 2014.

Evelyn, John. The Diary of John Evelyn. Ed. E.S. de Beer. 6 vols. Oxford: Clarendon Press, 1955.

Frison-Roches, Roger, and Jouty, Sylvain. A History of Mountain Climbing. Paris and New York: Flammarion, 1996.

Gilchrist, Paul. "Gender and British Climbing Histories: Introduction," Sport in History. 33.3. (2013): 223-235.

Gorak, Jan. The Making of the Modern Canon: Genesis and Crisis of a Literary Idea. London: Athlone, 1991.

Gosse, Edmund. Gray. London: Macmillan, 1882.

Heringham, Noah. Romantic Rocks, Aesthetic Geology. Ithaca, NY: Cornell University Press, 2004 .

Hollis, Dawn L. "Rethinking Mountains: Ascents, Aesthetics, and Environment in Early Modern Europe." Ph.D. thesis, University of St Andrews, 2016. 
Isserman, Maurice, and Weaver, Stewart. Fallen Giants: A History of Himalayan Mountaineering from the Age of Empire to the Age of Extremes. New Haven: Yale University Press, 2008.

Jackson Williams, Kelsey. "Canon before Canon, Literature Before Literature: Thomas Pope Blount and the Scope of Early Modern Learning." Huntington Library Quarterly. 77.2. (2014): 177199.

Koelb, Janice Hewlett. "'This Most Beautiful and Adorn'd World': Nicolson's Mountain Gloom and Mountain Glory Reconsidered." Interdisciplinary Studies in Literature and Environment, 16.3. (2009): 443-468.

König, Jason. "Strabo's Mountains." Valuing Landscape in Classical Antiquity: Natural Environment and Cultural Imagination. Eds. Jeremy McInerney and Ineke Sluiter. Leiden: Brill, 2016, 46-69.

Korenjak, Martin. "Why Mountains Matter: Early Modern Roots of a Modern Notion". Renaissance Quarterly 70.1. (2017): 179-219.

Longman, William. "Modern Mountaineering and the History of the Alpine Club." Addendum to Alpine Journal. VIII (1876-1878).

Macaulay, Thomas Babington. The History of England from the Ascension of James II. 8 vols. London: Longman, 1855.

Macfarlane, Robert. Mountains of the Mind: A History of a Fascination. London: Granta Books 2004 (first published 2003).

Mathews, C.E. "The Growth of Mountaineering." Alpine Journal. X. (1880-1882): 251-263.

Moore, Cecil. "The Return to Nature in English Poetry of the Eighteenth Century". Studies in Philology. 14:3. (1917): 243-291.

Neate, Jill. Mountaineering Literature: A Bibliography of Material Published in English. Milnthorpe, Cumbria, and Seattle, Washington: Cicerone Press and Mountainbooks, 1996. First published as W.R. Neate, Mountaineering and Its Literature: A Descriptive Bibliography of Selected Works Published in the English Language, 1744-1976. Milnthorpe: Cicerone Press, 1978.

Nicolson, Marjorie Hope. Mountain Gloom and Mountain Glory: The Development of the Aesthetics of the Infinite. New York: W.W. Norton \& Co., 1963; first published Cornell University Press, 1959.

Parsons, Glenn. "Freedom and Objectivity in the Aesthetic Appreciation of Nature." British Journal of Aesthetics. 46.1. (2006): 17-27. 
Peedom, Jennifer (dir.), and Macfarlane, Robert, Mountain. Madman Films, 2017.

Pollock, Sir Frederick. "The Early History of Mountaineering." Mountaineering. Ed. C.T. Dent. London: Badminton Library of Sports and Pastimes, 1892.

Prickett, Stephen. "Circles and Straight Lines: Romantic Versions of Tourism." The Making of Modern Tourism: The Cultural History of the British Experience, 1600-2000. Eds. Hartmut Berghoff, Barbara Korte, Ralf Schneider and Christopher Harvie. Basingstoke: Palgrave Macmillan, 2002, 69-84.

Ray, John. Miscellaneous Discourses Concerning the Dissolution and Changes of the World. London: printed for Samuel Smith, 1692.

Ray, John. Select Remains of John Ray. London: printed and sold by Ja. Dodsley, 176o.

Ring, Jim. How the English Made the Alps. London: John Murray, 2000.

Rueger, Alexander. "Experiments, Nature and Aesthetic Experience in the Eighteenth Century." British Journal of Aesthetics. 37.4. (1997): 305-322.

Ruskin, John. The Works of John Ruskin. Eds. E.T. Cook and Alexander Wedderman. 39 vols. London: George Allen, 1903-1912.

Sanzaro, Francis. "Keep Our Mountains Free. And Dangerous." The New York Times, Jan. 13, 2018. Www.nytimes.com/2018/01/13/opinion/sunday/keep-our-mountains-free-anddangerous.html. Accessed 09.03.2018.

Schama, Simon. Landscape and Memory. London: HarperCollins, 1995.

Shairp, James Campbell. On Poetic Interpretation of Nature. Edinburgh: David Douglas, 1877.

Shapsay, Sandra. "Contemporary Environment Aesthetics and the Neglect of the Sublime." British Journal of Aesthetics. 53.2. (2013): 181-198.

Simler, Josias. De sedunorum thermis et aliis fontibus medicates de Alpibus commentaries Vallesiae description. Zürich: excudebat Christoph II Froschaur, 1574.

Simler, Josias. "Vallesiae et Alpinum descriptio." Because It's There: A Celebration of Mountaineering from 200 B.C. to Today. Trans. and ed. Alan Weber. Lanham, Maryland: Taylor Trade Publishing, 2003.

Smout, T.C. Nature Contested: Environmental History in Scotland and Northern England since 1600. Edinburgh University Press, 2000. 
Stephen, Leslie. The Playground of Europe. London: Longmans, Green, and Co., 1871.

Stephen, Leslie. English Literature and Society in the Eighteenth Century. London: Duckworth, New Readers Library: 1927 (first published 1904).

Thomas, Keith. Man and the Natural World: Changing Attitudes in England, 1500-1800. London: Allan Lane, 1983.

Walsham, Alexandra. The Reformation of the Landscape: Religion, Identity, and Memory in Early Modern Britain and Ireland. Oxford University Press, 2011.

Wordsworth, William. Lyrical Ballads, with other poems. $2^{\text {nd }}$ ed. 2 vols. London: printed by T.N. Longman and O. Rees, 1800.

Originally printed in The Morning Post, 9 December 1844. Cited here in ed. Rev. Alexander B. Grosart, The Prose Works of William Wordsworth, 3 vols., vol. 2 Aesthetical and Literary (London: Edward Moxon, Son, and Co., 1876), pp. 325-333. 